\title{
Case Study-Green Revolution in Punjab
}

\author{
Dr. Shalini Jaiswal ${ }^{1} \mid$ Priyam Jain ${ }^{1} \mid$ Dr. Preeti Singh Bahadur ${ }^{1}$ \\ ${ }^{1}$ Amity University, Greater Noida Campus \\ To Cite this Article \\ Dr. Shalini Jaiswal, Priyam Jain and Dr. Preeti Singh Bahadur, "Case Study-Green Revolution in Punjab”, International \\ Journal for Modern Trends in Science and Technology, Vol. 06, Issue 07, July 2020, pp.:61-68; \\ https://doi.org/10.46501/IJMTST060709
}

Article Info

Received on 10-June-2020, Revised on 22-June-2020, Accepted on 26-June-2020, Published on 01-July-2020.

\section{ABSTRACT}

The adjustment of different current rural systems has additionally reinforced the job of rural division in the financial improvement and work age of Punjab. The editing force in Punjab is the most elevated among the Indian States; and the creation and efficiency of significant harvests expanded a few times because of the approach of Green Revolution. Be that as it may, the adjustment of new development system has limited the state to have just two harvests, i.e., wheat and paddy. Further it has brought about unhealthy soil, bother invaded crops, overexploited groundwater and water logging deserts. The goal of the Green revolution was to increase the efficiency of agricultural processes so that the productivity of the crops was increased and could help developing countries to face their growing population's needs.

The current paper is an endeavor to glance out the monetary advantages and environmental expense of the Green Revolution in Punjab. For this reason, the paper is isolated into two segments. The main area looks at the major monetary advantages of the Green Revolution in Punjab. The environmental expense has been investigated in the subsequent area.

KEYWORDS:- Fertilizers, Green Revolution, Socio-Economic, agricultural development

Copyright (C) 2014-2020 International Journal for Modern Trends in Science and Technology

DOI: https://doi.org/10.46501/IJMTST060709

\section{INTRODUCTION}

Green Revolution, its achievement, and limits in terms of agricultural productivity improvement, and its broader impact at social, environmental, and economic levels is provided.The phenomenon of Green Revolution is identified with India is being catapulted from a chronically food deficient country, with abegging bowl image, to one which was self- sufficient, and which became over time even surplus in food. ${ }^{1}$

The Green Revolution in India was initiated in 1965 (in certain state like Punjab, Haryana, and Uttar Pradesh) under leadership of Lal Bahadur Shastri ${ }^{2-4}$ to increase in food grain production,. The effect of this initiative was the expansion of HYV of wheat, ${ }^{5}$ and rust resistant strains of wheat.6,7 But according to M.S. Swaminathan ${ }^{8}$ and Vandana Shiva green revolution caused sociological and financialproblems Punjab and Haryana people. ${ }^{9}$ Regionally, in India, the greatest effect of the GreenRevolution has occurred in the wheat growing areas of Punjab, Haryana andWestern U.P. In South India, the effects of Green Revolution have beenconcentrated in the States of Andhra, Tamil Nadu and Kerala.The Rates of return to growers are highest in "wheat, paddy, and cashcrops. ${ }^{10}$ The highest rates of return for wheat are in Punjab,Haryana, Rajasthan. Insofar as paddy is concerned, the rates ofreturn per hectare are highest in Karnataka, Punjab, Haryana. Takingall majorcrops together, the high productivity, high profit States are Punjab, Haryana, Gujarat and 
Tamil Nadu. ${ }^{11}$. The average yield of ricewent up by 60.1 percent in the period from 1969-70 to 1988-89,whereas it went up by 97.1 percent for wheat.The use of genetic engineering in agriculture to create genetically modified foods is viewed by some as the natural continuation of the Green revolution. ${ }^{12}$

\section{MERITS OF GREEN REVOLUTION}

From the financial perspective, the farming in the State of Punjab has gained breathtaking ground during the most recent three decades and there is by all accounts no equal model anyplace on the planet history of rural improvement ${ }^{13}$. The State of Punjab was known as the 'Breadbasket' of India because of its agrarian exhibition in 1970s and 1980s. The nourishment surpluses from Punjab have been the foundation of the national nourishment framework. Even though, Punjab includes just 1.5 percent of the complete topographical region of the nation, it produces 21 percent of wheat, 10 percent of rice and 8 percent of cotton creation in the nation. The State is contributing more than 50 percent of wheat and rice in the focal pool ${ }^{14}$. he major financial additions of Green Revolution have been inspected by concentrating on the accompanying focuses.

\section{A. GSDP and Employment}

The creation structure of Punjab is vigorously overwhelmed by essential division exercises. Because of the approach of present-day strategies for development, the horticulture area of Punjab turns intothe pioneer in financial improvement. Because of Punjab economy, farming segment established 54.27 percent in GSDP in 1970-71 which gradually boiled down to 29.87 percent in 2008-09. Be that as it may, if we contrast the portion of agribusiness area and the portion of mechanical or dynamic division it is still very high. It is appropriate to take note of that in spite of fast automation of farming exercises in Punjab since the mid-sixties the horticulture area is as yet having a significant influence in business age. In 1971, out of the all-out workforce 62.67 percent was working in the farming segment and following three decades time span it diminished to 38.95 percent in 2001 . The portion of horticulture segment in business is extremely high in contrast with the modern area. As far as utilizing the workforce, the modern segment of Punjab shows an opposite inclination. The portion of modern area in work of the absolute workforce was 11.30 percent in 1970-71 and it diminished to 8.41 percent in 2001. After the time of four many years of the coming of Green Revolution and capital-intensive methods of creation in country economy of Punjab a generous extent of workforce despite everything rely upon the horticulture division for their job. Along these lines, it is the farming division which has not just the development driver of the GSDP of the State yet additionally a significant wellspring of pay for a huge extent of the absolute populace.

\section{B. Alterin Land Consumption}

The amount and nature of land assets in a specific district assumed a significant job in the horticultural advancement. Aside from a piece of Shivalik slopes along its eastern outskirt, the whole zone of Punjab is level and plain. Punjab has generally been the place that is known for five waterways that is the reason the place where there is this district is highly profitable.

In the only remaining century, the State's land limits have been moved twice - the savage parcel of India in 1947 and the managerial division of Punjab in 1966 into present day Haryana and Himachal Pradesh. Presently, Punjab envelops complete land region of 5033 thousand hectares, which establishes about 1.53 percent of all out geological territory of the nation. The land use example of the State indicated that out of the complete geological region around 83 percent is the net planted territory (Table 1).

\begin{tabular}{|c|c|c|c|c|c|c|}
\hline Items & $\begin{array}{l}1960 \\
-61\end{array}$ & $\begin{array}{l}1970 \\
-71\end{array}$ & $\begin{array}{l}1980 \\
-81\end{array}$ & $\begin{array}{l}1990 \\
-91\end{array}$ & $\begin{array}{l}2000 \\
-01\end{array}$ & $\begin{array}{l}2008 \\
-09\end{array}$ \\
\hline $\begin{array}{l}\text { Topograp } \\
\text { hical Area }\end{array}$ & 5036 & 5036 & 5036 & 5036 & 5036 & 5036 \\
\hline $\begin{array}{l}\text { Area } \\
\text { Under } \\
\text { Jungle }\end{array}$ & 35 & 123 & 216 & 222 & 280 & 296 \\
\hline $\begin{array}{l}\text { Un-cultu } \\
\text { ral and } \\
\text { Barren } \\
\text { Land }\end{array}$ & - & 208 & 96 & 83 & 28 & 23 \\
\hline $\begin{array}{l}\text { Land put } \\
\text { to } \\
\text { Non-farm } \\
\text { ing Use }\end{array}$ & - & 416 & 436 & 343 & 410 & 494 \\
\hline $\begin{array}{l}\text { Uncultur } \\
\text { able } \\
\text { Land } \\
\text { Prohibiti } \\
\text { ng } \\
\text { Fallow } \\
\text { Land }\end{array}$ & 255 & 92 & 49 & 57 & 22 & 10 \\
\hline $\begin{array}{l}\text { Fallow } \\
\text { Land }\end{array}$ & 313 & 139 & 45 & 110 & 43 & 39 \\
\hline $\begin{array}{l}\text { Net } \\
\text { Sown } \\
\text { Area }\end{array}$ & 3757 & 4053 & 4191 & 4218 & 4250 & 4171 \\
\hline $\begin{array}{l}\text { Cropped } \\
\text { Area }\end{array}$ & 4732 & 5678 & 6763 & 7502 & 7941 & 7912 \\
\hline $\begin{array}{l}\text { Cropping } \\
\text { Intensity } \\
(\%)\end{array}$ & 126 & 140 & 161 & 178 & 186 & 189 \\
\hline
\end{tabular}


Because of innovation and exploitation of creation relations the unculturable and fruitless land is persistently falling since 1970 s. It $1970-71$ it was was 208 thousand hectares and 2008-2009 it falling to 23 thousand hectares. Thus, the new method of creation in Punjab's horticulture likewise brought increasingly more territory of neglected land under development. The decrepit land declined from 313 thousand hectares in 1960-61 to 110 thousand hectares in 1990-91; and it further declined to 39 thousand hectares in 2008-09. The land put on non-farming purposes remains practically same during the period when the Green Revolution, since the agrarian advancement leaves no space for the infiltration into different occupations in Punjab.

The decrepit land declined from 313 thousand hectares in 1960-61 to a hundred and ten thousand hectares in 1990-91; and it any declined to thirty-nine thousand hectares in 2008-09. The

land placed on non-farming functions remains much same thr oughout the amount once the revolution, since the rural advancement leaves no house for the infiltration into completely different occupations in geographic region.

The table additionally shows that because of new strategies of creation the net planted zone has likewise expanded from 3757 thousand hectares in 1960-61 to 4218 thousand hectares in 1990-91; and it imperceptibly declined to 4171 thousand hectares in 2008-09. The decrease in net planted region has been because of the quick development of urban zone in various pieces of the State. Additionally, because of western vision of way of life the Punjabis are consistently moving towards better occupants. The cropped region has additionally advanced from 4732 thousand hectare to 7912 thousand hectares between 1960-61 and 2008-09. The cropping force has additionally advanced from 126 of every $1960-61$ to 189 out of 2008-09. The presentation of current techniques for development not just assisted with expanding the region under development however it additionally assumed a positive job in the change of customary strategies for development.

\section{Manufacture and Outputdevelopment}

The farming in Punjab made fast walks since autonomy. A portion of the components which contributed towards early advancement incorporate the laborer owner overwhelmed agrarian structure, early finish of combination of property, augmentation of water system offices, reinforcing the co-usable credit structure, assembling a vehicle, promoting and capacity, foundation, horticulture investigate and persevering workers. After the redesign of the State in 1966, which by chance likewise concurred with the approach of new horticultural innovation quickened the development procedure in the State. At the underlying stage, Green Revolution in Punjab was limited to wheat simply because customarily Punjab has never a rice developing zone. In any case, following a couple of years, new assortments of rice additionally got famous with the ranchers ${ }^{7}$. After the presentation of new strategies for development the creation and profitability expanded forcefully in Punjab which offered lift to the general development of the economy. Theefficiency of the considerable number of crops in Punjab has expanded after the presentation of new strategies for development, however the profitability of rice and wheat expanded at an a lot quicker rate in contrast with different crops. The production of wheat expanded from 1244 $\mathrm{kg} /$ hectare in 1960-61 to $4507 \mathrm{~kg} /$ hectare in 2007-08. So also, the creation of rice has likewise expanded from $1009 \mathrm{~kg} /$ hectare to $4019 \mathrm{~kg} /$ hectare during a similar period. It is critical to take note of that inside as length of four decades the normal efficiency of wheat and rice has expanded right around multiple times.The whole increment in production is highlighted in Table 2. All crops but maize, grams, rapeseed \& mustard, and groundnut have appeared an increment in generation. The production of wheat and rice has been much higher in comparison to other crops.

Table 2, Growth in overall Production of crops

\begin{tabular}{|c|c|c|c|c|c|c|}
\hline Crops & $\begin{array}{l}1960- \\
61\end{array}$ & $\begin{array}{l}1970- \\
71\end{array}$ & $\begin{array}{l}1980- \\
81\end{array}$ & $\begin{array}{c}1990 \\
91\end{array}$ & $\begin{array}{c}2000- \\
01\end{array}$ & $\begin{array}{c}2008- \\
09\end{array}$ \\
\hline Wheat & 1742 & 5145 & 7677 & $\begin{array}{c}1215 \\
9\end{array}$ & $\begin{array}{c}1555 \\
1\end{array}$ & $\begin{array}{c}1573 \\
3\end{array}$ \\
\hline Rice & 229 & 688 & 3233 & 6506 & 9157 & $\begin{array}{c}1100 \\
0\end{array}$ \\
\hline Maize & 371 & 861 & 612 & 333 & 461 & 514 \\
\hline Barley & 52 & 57 & 108 & 101 & 109 & 55 \\
\hline Gram & 7 & 284 & 150 & 45 & 8 & 3 \\
\hline Bajra & - & 243 & 86 & 13 & 5.2 & 5 \\
\hline $\begin{array}{c}\text { Sugarca } \\
\text { ne }\end{array}$ & 486 & 527 & 392 & 601 & 777 & 467 \\
\hline $\begin{array}{c}\text { Cotton } \\
\text { (A) }\end{array}$ & 709 & 818 & 1178 & 1909 & 1199 & 2285 \\
\hline $\begin{array}{c}\text { Rapesee } \\
\text { d \& } \\
\text { Mustar } \\
\text { d }\end{array}$ & - & 77 & 69 & 67 & 61 & 34 \\
\hline $\begin{array}{c}\text { Ground } \\
\text { nut }\end{array}$ & - & 169 & 104 & 9 & 4 & 3 \\
\hline
\end{tabular}


The creation of wheat has expanded from 1742 thousand tones in 1960-61 to 15733 thousand tons in 2008-09. Additionally, the creation of rice likewise expanded from 229 thousand tons to 11000 thousand tons during a similar period. It is because of the explanation that successful help cost is accessible for the paddy and wheat crops.

\section{DRAWBACK OF GREEN REVOLUTION}

It is very hard to figure the fiscal estimations of a wide range of ecological debasement. In any case, it is conceivable to realize that how much natural quality is being given for the sake of horticultural improvement. India accomplished independence in nourishment creation just because of Green Revolution. $\mathrm{Be}$ that as it may, this was accomplished at an incredible expense country, both natural and social ${ }^{15}$. Farming financial experts in India have been intrigued basically in the monetary advantages of crop creation. Their enthusiasm for country biology has been immaterial 16. In serious cropping framework, the extreme and unseemly utilization of agrochemical contaminates conduits, harms individuals and upsets eco-framework . Significantly, after the four many years of Green Revolution, Punjab is neither a place where there is success nor harmony. It is a district ridden with discontent and savagery. Rather than bounty, Punjab has been left with ailing soil, bug plagued crops, groundwater consumption, water logging deserts and obliged and malcontented ranchers ${ }^{17}$. The adjustment of new system of development has raised numerous social and ecological issues. The model of concentrated development brought forth various biological issues in Punjab.

\section{A. Unsustainable Cropping Pattern}

The most sensational change in the cropping design is unmistakably the substitution of the different cropping designs with a cropping design ruled byonly two crops. Toward the beginning of the Green Revolution HYV seeds were accessible just for scarcely any crops which changed the cropping design unfavorably from blended cultivating to monoculture (wheat-paddy cycle). From that point forward all over Punjab, the wheat-paddy cycle has come to command the cropping design.

Table-3, shift in cropping Pattern

\begin{tabular}{|c|c|c|c|c|c|c|}
\hline Crops & $\begin{array}{l}1960 \\
-61 \\
\end{array}$ & $\begin{array}{l}1970- \\
71\end{array}$ & $\begin{array}{l}1980 \\
-81 \\
\end{array}$ & $\begin{array}{l}1990 \\
-91 \\
\end{array}$ & $\begin{array}{l}2000 \\
-01 \\
\end{array}$ & $\begin{array}{l}2008 \\
-09 \\
\end{array}$ \\
\hline Rice & $\begin{array}{l}227 \\
(5.19)\end{array}$ & $\begin{array}{l}390 \\
(8.30)\end{array}$ & $\begin{array}{l}1183 \\
(20.52)\end{array}$ & $\begin{array}{l}2015 \\
(30.96)\end{array}$ & $\begin{array}{l}2612 \\
(37.52)\end{array}$ & $\begin{array}{l}2735 \\
(38.17)\end{array}$ \\
\hline $\mathrm{Ma}$ & $\begin{array}{l}327 \\
(7.48) \\
\end{array}$ & $\begin{array}{l}555 \\
(11.82)\end{array}$ & $\begin{array}{l}382 \\
(6.63) \\
\end{array}$ & $\begin{array}{l}188 \\
(2.89) \\
\end{array}$ & $\begin{array}{l}165 \\
(2.37)\end{array}$ & $\begin{array}{l}151 \\
(2.11)\end{array}$ \\
\hline
\end{tabular}

\begin{tabular}{|c|c|c|c|c|c|c|}
\hline $\begin{array}{l}\text { Bajra } \\
\text { Jawhar }\end{array}$ & $\begin{array}{l}129 \\
(2.95) \\
\end{array}$ & $\begin{array}{l}207 \\
(4.40) \\
\end{array}$ & $\begin{array}{l}69 \\
(1.20) \\
\end{array}$ & $\begin{array}{l}12 \\
(0.18) \\
\end{array}$ & $\begin{array}{l}6 \\
(0.09) \\
\end{array}$ & $\begin{array}{l}5 \\
(0.07) \\
\end{array}$ \\
\hline $\begin{array}{l}\text { Ground } \\
\text { nut }\end{array}$ & $\begin{array}{l}679 \\
(15.54) \\
\end{array}$ & $\begin{array}{l}174 \\
(3.70) \\
\end{array}$ & $\begin{array}{l}83 \\
(1.44)\end{array}$ & $\begin{array}{l}11 \\
(0.17)\end{array}$ & $\begin{array}{l}4 \\
(0.06)\end{array}$ & $\begin{array}{l}3 \\
(0.04)\end{array}$ \\
\hline Cotton & $\begin{array}{l}447 \\
(10.22) \\
\end{array}$ & $\begin{array}{l}397 \\
(8.45) \\
\end{array}$ & $\begin{array}{l}649 \\
(11.26) \\
\end{array}$ & $\begin{array}{l}701 \\
(10.77) \\
\end{array}$ & $\begin{array}{l}474 \\
(6.81) \\
\end{array}$ & $\begin{array}{l}527 \\
(7.35) \\
\end{array}$ \\
\hline $\begin{array}{l}\text { Sugarc } \\
\text { ane }\end{array}$ & $\begin{array}{l}133 \\
(3.04)\end{array}$ & $\begin{array}{l}128 \\
(2.72)\end{array}$ & $\begin{array}{l}71 \\
(1.23)\end{array}$ & $\begin{array}{l}101 \\
(1.56)\end{array}$ & $\begin{array}{l}121 \\
(1.74)\end{array}$ & $\begin{array}{l}81 \\
(1.13)\end{array}$ \\
\hline $\begin{array}{l}\text { Sesarm } \\
\text { um }\end{array}$ & $\begin{array}{l}8 \\
(0.18) \\
\end{array}$ & $\begin{array}{l}15 \\
(0.32) \\
\end{array}$ & $\begin{array}{l}17 \\
(0.29)\end{array}$ & $\begin{array}{l}18 \\
(0.28) \\
\end{array}$ & $\begin{array}{l}19 \\
(0.27) \\
\end{array}$ & $\begin{array}{l}8 \\
(0.11)\end{array}$ \\
\hline Wheat & $\begin{array}{l}1400 \\
(32.04) \\
\end{array}$ & $\begin{array}{l}2299 \\
(48.91)\end{array}$ & $\begin{array}{l}2812 \\
(48.78)\end{array}$ & $\begin{array}{l}3273 \\
(50.29) \\
\end{array}$ & $\begin{array}{l}408 \\
(48.95)\end{array}$ & $\begin{array}{l}3526 \\
(49.20) \\
\end{array}$ \\
\hline Barley & $\begin{array}{l}66 \\
(1.51)\end{array}$ & $\begin{array}{l}57 \\
(1.21)\end{array}$ & $\begin{array}{l}65 \\
(1.13)\end{array}$ & $\begin{array}{l}37 \\
(0.57)\end{array}$ & $\begin{array}{l}32 \\
(0.46)\end{array}$ & $\begin{array}{l}16 \\
(0.22)\end{array}$ \\
\hline Gram & $\begin{array}{l}838 \\
(19.18)\end{array}$ & $\begin{array}{l}358 \\
(7.62)\end{array}$ & $\begin{array}{l}258 \\
(4.48)\end{array}$ & $\begin{array}{l}60 \\
(0.92)\end{array}$ & $\begin{array}{l}6 \\
(0.09)\end{array}$ & $\begin{array}{l}3 \\
(0.04)\end{array}$ \\
\hline $\begin{array}{l}\text { Rapese } \\
\text { eds } \\
\& \text { Musta } \\
\text { rd }\end{array}$ & $\begin{array}{l}107 \\
(2.46)\end{array}$ & $\begin{array}{l}103 \\
(2.19)\end{array}$ & $\begin{array}{l}136 \\
(2.36)\end{array}$ & $\begin{array}{l}69 \\
(1.06)\end{array}$ & $\begin{array}{l}55 \\
(0.79)\end{array}$ & $\begin{array}{l}29 \\
(0.41)\end{array}$ \\
\hline Potato & $\begin{array}{l}9 \\
(0.21) \\
\end{array}$ & $\begin{array}{l}17 \\
(0.36) \\
\end{array}$ & $\begin{array}{l}40 \\
(0.69) \\
\end{array}$ & $\begin{array}{l}23 \\
(0.35) \\
\end{array}$ & $\begin{array}{l}60 \\
(0.86) \\
\end{array}$ & $\begin{array}{l}82 \\
(1.15) \\
\end{array}$ \\
\hline
\end{tabular}

Table 3 uncovers that in 1960-61 wheat involved a territory of 1400 thousand hectares, gram 838 thousand hectare, maize 327 thousand hectares, and rice 227 thousand hectares with all out cropped zone of 32.04 percent, 15.54 percent, 7.48 percent and 5.19 percent separately in Punjab. By 2008-09 of the all-out cropped territory, the zone under wheat and rice expanded to 49.20 percent and 38.17 percent, though gram and maize diminished to 0.04 percent and 2.11 percent individually. In this manner, the zone under wheat and rice went up from 37.23 percent in $1960-61$ to 87.37 percent in 2008-09.

Various components have contributed towards the antagonistic change in the cropping design. The administration strategies at the beginning period of Green Revolution were a lot of answerable for the move in cropping design. The accessibility of HYV seeds just for a couple of crops, the accessibility of legitimate promoting including bolster cost and obtainment component for chose crops assumed a positive job to make the cropping design unreasonable. The western vision of agrarian advancement and commercialization of horticultural exercises likewise assumed a critical job to change the brain science of the Punjabi ranchers to move towards the impractical cropping design. Presently, the State has lost its number of conventional crops which were not just accommodating for adjusting the utilization example of cultivating families yet additionally valuable for keeping up the dirt ripeness and micronutrients of the dirt. The decrease in the territory under heartbeats and increment in region under crossover wheat-paddy cycle seriously affects the fruitfulness of soil. The expulsion of heartbeats 
from cropping design has evacuated a significant wellspring of free nitrogen for the dirt.

\section{B. Unmanageable Groundwater Misuse}

It is the fake water system framework which is a central point behind the accomplishment of Green Revolution in Punjab. The groundwater is assuming a significant job for the horticultural advancement since precipitation meets 20 percent of water system necessities. By and by, a significant worry of the State is the quick decay of water table. Around 77 percent region of Punjab is confronting the issue of falling water table. To meet the current degree of crop creation, the interest in water surpasses its stockpile from various sources. The abundance request is met through the over-abuse of groundwater, becauseof which groundwater table is progressively going down ${ }^{18}$. The diminutive person assortments of wheat and rice need a lot higher water system in contrast with the desi verities. The presentation of paddy in late 1970s was likely the most significant purpose for theexpansion in territory under counterfeit water system by tubewells and wells. Figure 1 shows that net watered region by trenches has diminished from 44.53 percent in $1970-71$ to 27.31 percent in 2008-09. Then again, the region watered by tube wells hasexpanded from 55.09 percent in 1970-71 to 72.59 percent in $2008-09$. The primary purpose for such a tremendous misuse of groundwater was that the surface water couldn't fulfill the need of farming segment.

Because of the unreasonable misuse of groundwater, the degree of groundwater in Punjab is exhausting pointedly. Out of the 118 squares in 1986, 55 were overexploited, 9 squares were basic, 18 squares were semi-basic and 36 were protected. In any case, the circumstance turned out to be a lot of more terrible in 2005. In 2005 out of 137 squares 103 were overexploited, 4 squares were basic, 5 squares were semi-basic and just 25 squares were sheltered1912. The groundwater in Punjab is being overdrawn to such a degree, that water table has tumbled to the levels that make siphoning troublesome and excessively exorbitant. Little ranchers with little assets are frequently uncertain for water right and generally influenced. The consumption of groundwater can not a reason for major natural emergency however it is likewise a significant explanation for the expansion in cost of development in Punjab. The exhaustion of groundwater has constrained the ranchers to supplant the conventional siphon sets by costly submersible siphon sets.

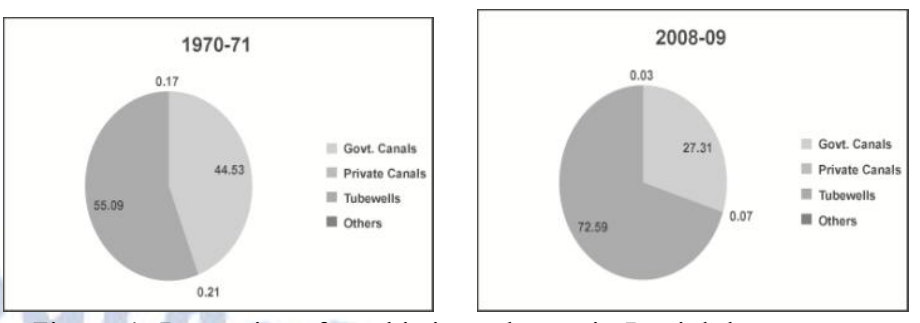

Figure 1: Proportion of total irrigated area in Punjab by sourse

\section{Unexpected Canal Irrigation Structureand Difficultyof Water Logging}

Poor water the board is prompting land debasement in inundated regions through salinization and water logging. Water logging is because of over the top utilization of water for momentary grain and inability to make move to deplete abundance water. The financial analysts focused more on the effect of water system on profitability of land, instead of on water use proficiency. Because of the impromptu trench water system framework and deficient seepage framework the south western locale of the State has been confronting the extreme issue of water logging and resultant soil saltiness. Both saltiness and water logging happen when horticultural land is over inundated. As second or third crops were arranged every year after the presentation of new agrarian technique, the circumstance turns out to be more terrible in the State.

The spontaneous trench water system framework in Bhakra told zones brought forth the issue of water logging and salinization in Punjab. Table -4delineates that the region submerged logging was 233400 hectares in the year 1998 and it diminished to 12000 hectare in 2006 . This reduction was not because of the administration endeavors and arrangements. The significant purpose for the decline in territory submerged logging was the lower precipitation in Punjab. The zone is still high under this serious issue. The issue is for the most part amassed in the locale of Faridkot, Ferozepur. Bathinda and Muktsar.

Table 4: Area under water logging in Punjab (In hectare)

\begin{tabular}{|l|l|}
\hline Year & $\begin{array}{l}\text { Area under water } \\
\text { logging }\end{array}$ \\
\hline 1998 & 233400 \\
\hline 2000 & 95700 \\
\hline 2002 & 30000 \\
\hline 2004 & 15500 \\
\hline
\end{tabular}


Because of waterlogging the degree of groundwater rises and when it spans to the crops root zone, it begins to seriously affect crop profitability, at last making the land absolutely useless and rendering the land into wet desert. This water breaks up the salts from the dirt and carries them to the surface when they are saved of the water dissipation. This brought about the salinization of soil, again influencing profitability antagonistically. Water logging does not influence just horticulture creation and soil richness, yet it additionally devastatingly affects trees, streets, structures, and framework ${ }^{20}$.

\section{HEALTH IMPACT DUE TO CHEMICAL COMPOSTS AND INSECTICIDE}

The expanding utilize of chemical fertilizers and pesticides is one of the major reasons behind the natural emergency in Punjab's horticulture. The over the top utilize of nitrogen fertilizer and pesticides has expanded the concentration of nitrates and pesticide leftover in soil, water, nourishment and nourish.

the beginning stages of Green Transformation, Government

India declared fertilizer appropriation to energize $t$ he agriculturists towards the HYV seeds. In comparison to the other states of India, the ranchers of Punjab slanted more towards the HYV seeds and for the utilization of fertilizers. In 1965-66, Punjab was slacking a number of States (most outstandingly, Tamil Nadu, Kerala and Andhra Pradesh) in respect to per hectare fertilizer consumption. After 1965-66, the per hectare utilization of

fertilizers expanded so strongly in Punjab that it cleared out all other States distant behind (Chadha, 1986). Punjab is presently expending over 8 per cent of the full fertilizer utilization of India. Figure 2 highlights the utilization of chemical fertilizers in Punjab. The utilization of nitrogen in Punjab was fair 175 thousand supplements ton in 1970-71 which expanded approximately seven-fold to 1332 thousand supplements ton 2008-09. Additionally, the utilization of add up to NPK expanded approximately eight-fold from 213 supplements ton in 1970-71 to 1768 supplement ton in 2008-09. There is intemperate utilize of nitrogen fertilizer and underutilization of other fertilizers and micronutrients which make antagonistic impact on soil's wellbeing and lack of a few vital nutrients. is one of the significant explanations for the natural emergency in Punjab's farming. The exorbitant utilization of nitrogen compost and pesticides has expanded the convergence of nitrates and pesticide leftover in soil, water, nourishment, and feed.

In the underlying phases of Green Revolution, Government of India reported compost endowment to energize the ranchers towards the HYV seeds. In contrast with different conditions of India, the ranchers of Punjab slanted more towards the HYV seeds and for the utilization of composts. In 1965-66, Punjab was lingering behind various States (most eminently, Tamil Nadu, Kerala and Andhra Pradesh) concerning per hectare compost utilization. After 1965-66, the per hectare utilization of composts expanded so forcefully in Punjab that it left all different States a long ways behind. Punjab is presentlydevouring more than 8 percent of the all out compost utilization of India.

Figure 2 highlights the utilization of concoction composts in Punjab. The utilization of nitrogen in Punjab was only 175 thousand supplements ton in 1970-71 which expanded around seven-crease to 1332 thousand supplements ton in 2008-09. Likewise, the utilization of complete NPK expanded around eight-overlap from 213 supplements ton in $1970-71$ to 1768 supplement ton in 2008-09. There is extreme utilization of nitrogen manure and under use of different composts and micronutrients which make unfavorable impact on soil's wellbeing and insufficiency of some significant supplements.

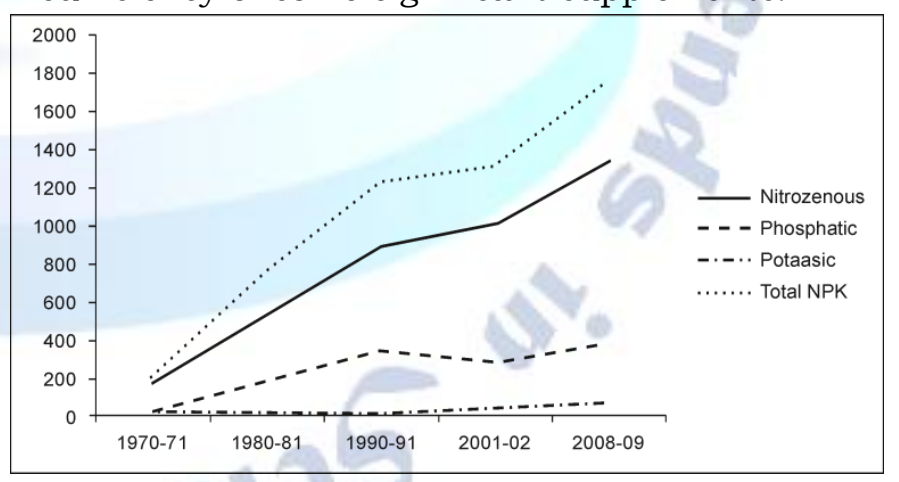

Figure 2: Utilization of chemical Composts in Punjab (000 Nutrients Ton)

Most definitely, Punjab is again at the top among the Indian satiates. The utilization of pesticides in Punjab expanded from 32000 metric tons (MT) in the year 1980-81 to 5970 MT in 2005-06. Right now, the State is expending around 17 percent of all out pesticides utilized in India. Out of these, more than 90 percent of pesticides are utilized in the development of cotton, rice and vegetables. An 
examination of per hectare utilization of the pesticides with different States shows that Punjab was at the top by expending 923 grams pesticides for every hectare ${ }^{21}$.

The extreme utilization of concoction pesticides cannotinfluence the $\mathrm{PH}$ level of soil and water, yet additionally making unfavorable impact on the wellbeing of people and creatures. It is one of the significant purposes for the expansion in malignancy cases in various pieces of Punjab because the nourishment eaten by us is highly pesticide defiled. The investigation led by Post Graduation Institute of Medical Education andResearch about the impact of concoction pesticides on human wellbeing in cotton belt of Malwa locale of the State indicated that the greater part of the pesticides produced in the nation are assessed to be utilized on cotton crop. The examination attempted to see whether cotton development, which is significantly more pesticide subordinate than rice and wheat, could be connected to malignant growth. An all out populace of 39,732 families including 183,243 individuals was reviewed in 129 towns of square Talwandi Sabo of Bathinda area, and Chamkaur Sahib square of Ropar locale. The quantity of malignancy cases in Talwandi Sabo square was 103 for each lakh people contrasted with 71 for each lakh people in Chamkaur Sahib square 22,23 Along these lines, the event of malignancy cases in cotton belt of Punjab shows that the utilization of unreasonable pesticides can't making an antagonistic impact on country nature, yet it is likewise influencing the strength of the cultivating families. The consuming of rural wastage in the wake of harvesting crops andextreme utilization of apparatus are contributing towards ecological contamination.

\section{CONCLUSION}

The above investigation gives that from the financial perspective the State of Punjab gained staggering ground after the presentation of innovation of development. With 1.53 percent of the complete geological territory of the nation, Punjab is contributing around 50 percent of wheat and rice to the national pool. Agribusiness division is assuming a significant job in the auxiliary organization of the economy and contributing a huge extent in GSDP and work. The ranchers of Punjab are utilizing every single piece of the dirt for development purposes. That is the reason the net planted zone in Punjab is the highest when contrasted with different pieces of the nation. Essentially, after the presentation of new strategies for development the cropping power in Punjab arrived at its immersion level. The creation relations in Punjab's agribusiness totally moved from conventional to present day farming. The augmentation of water system offices and declaration of least help cost expanded the profitability of wheat and rice around multiple times. The absolute creation of chief crops (wheat and rice) likewise expanded strongly. This advancement builds up Punjab as one of the most extravagant State in financial terms.Punjab has been experiencing a ton the natural perspective. The overwhelming information-based agribusiness is influencing every single part of nature and human wellbeing, regardless of whether it's cropping design, access to groundwater, cost of development and soil fruitfulness. The escalated cropping changed the cropping design from various cropping example to monoculture overwhelmed by wheat and rice. The new assortments of wheat and paddy need substantially more water system in contrast with desi assortments. It is one of the significant reasons that the zone under fake water system (tubewells and wells) has expanded pointedly. The overexploitation of groundwater because of the fake water system framework definitely drained the groundwater table in Punjab. The water table in the State has been exhausting at the pace of $60 \mathrm{~cm}$ every year during the previous two years. The groundwater misuse has reached at a disturbing pace of 110 percent which implies that more water is being utilized than revived. Then again, the spontaneous channel water system framework in the south western locale of the State has brought forth issues of water logging and soil saltiness. The broad utilization of substance manures and pesticides has additionally contributed to a great extent in the natural emergency of Punjab. Punjab is at the top among the Indian States in the utilization of concoction composts and pesticide utilization. It has not just made an unfriendly impact on soil wellbeing yet in addition on creature and human wellbeing.

In this way, the Green Revolution has carried thriving to the State as well as upset environmental equalization of the State. Presently, it's an ideal opportunity to reexamine about the Punjab's model of rural development. There is a pressing need to substitute the unreasonable strategies for development with maintainable and ecological benevolent techniques. The green farming which 
includes coordinated bug the executives and supplement supply ought to be advanced. It is advantageous for keeping up the profitability of our dirt and spare our regular assets. To advance the green horticulture the rhythm of open venture ought to be changed from superfluous consumptions. The information, exposure and modest institutional credit offices to the ranchers are the fundamental conditions to advance natural cultivating in the State.

\section{POLITICS IMPLICATIONS}

The existence of various organizations such as Punjab Khetibari Zamindar Union, Khet Mazdoor Sabha, Kisan Sabha, Dehati Mazdoor Sabha and Zimindara Union is the proof of increasing political consciousness among the farmers and landless labour. These Kisan organizations have been continuing struggles on behalf of landless on various issues in different areas of the state. The youth and students wings of the CPS-SFI, AISF, PSU, DYFI are also trying to increase their hold among the landless and the marginal and poor peasants.

With the advent of the Green Revolution, the political structure of Punjab underwent tremendous change. Rural population of Punjab had already started participating in political activities of the state after independence when the adult franchise was introduced in the country. Spread of education among the peasantry was another contributory factor. It created social awareness and enhanced greater participation in the political process. But a major change in the political structure of Punjabcame after the coming of the Green Revolution. Farmers started dominating in the political scene. The politics of farmers no longer remained limited to village Panchayat elections. They were the dominate factor both at state and at all India level. With the changed political conditions, the numerical strength of agricultural labour was a great attraction for the political parties.

\section{REFERENCES}

[1] Article Green Revolution, Wikipedia Brar, K. K. (1999), Green Revolution: Ecological Implications, Dominant Publishers, New Delhi

[2] "From Green to Ever-Green Revolution". The Financial Express. 10 August 2009. Retrieved 16 April 2020.

[3] Biography, World Leaders (23 February 2017). "All About The Green Revolution By Indira: Impacts and Path Ahead". Medium. Retrieved 16 April 2020.

[4] "The Stories of Ehrlich, Borlaug and the Green Revolution". thewire.in. Retrieved 16 April 2020.

[5] Jump up to:a b "About IARI". IARI. Retrieved 11 June 2015.
[6] Jump up to: $\mathbf{a}^{\mathbf{b}}$ "Rust-resistant Wheat Varieties. Work at Pusa Institute". The Indian Express. 7 February 1950. Retrieved 13 September 2013.

[7] Newman, Bryan. "A Bitter Harvest: Farmer Suicide and the Unforeseen Social, Environmental and Economic Impacts of the Green Revolution in Punjab, India ." Development Report No. 15. Jan 2007. Food First: Institute for Food and Development Policy. Retrieved 16 November 2018 from https://digitalcommons.unl.edu/cgi/viewcontent.cgi? article $=1027 \&$ context $=$ envstudtheses

[8] "Founder: Prof M S Swaminathan". M S Swaminathan Research Foundation. 26 July 2016. Retrieved 16 April 2020.

[9] Shiva, Vandana. "Green revolution in India". Living heritage. Retrieved 5 March 2019.

[10] Sarthi Acharya, "Rates of Return in Indian Agriculture",EPW, XXVII, No 3 (January 18,1992),p.112.

[11] Sarthi Acharya, "Rates of Return in Indian Agriculture",EPW, XXVII, No 3(January 18,1992),p.119.

[12] World Development Report (2008), Agriculture for Development, Oxford University Press, Washington.

[13] Rangi, P. S; and Sidhu, M.S. (1998), "Growth of Punjab Agriculture: A Critical Appraisal", in Dhaliwal, G.S. et al. (eds.), Ecological Agriculture and Sustainable Development, Vol.2, Ecological Society, Ludhiana and Centre for Research in Rural and Industrial Development, Chandigarh.

[14] Gupta, S. P. (2004), The Punjab: An Overview, ESS PEE Publications, Chandigarh. Singh, S. (2000), "Crisis in Punjab Agriculture", Economic and Political Weekly, Vol.34, No.26.

[15] Sidhu, S. (2004), "Agrarian Crisis in Punjab (Genesis, Government's Response and International Experience)", Paper Presented at National Seminar, Punjabi University, Patiala.

[16] Ramakrishnan, P. S. (2008), Ecology and Sustainable Development: Working with Knowledge System, National Book Trust, New Delhi

[17] Rao, H. (1988), "Agricultural Development and Ecological Degradation: An Analytical Framework", Economic and Political Weekly, Vol. 23, No. $52 \& 53$. 